\title{
Terrorist Incidents and Tourism Demand: Evidence from Greece
}

\author{
Aristeidis Samitas ${ }^{1 *}$, Dimitrios Asteriou ${ }^{2}$, Stathis Polyzos ${ }^{3}$, Dimitris Kenourgios ${ }^{4}$ \\ ${ }^{I}$ Zayed University, College of Business, Abu Dhabi, UAE \\ ${ }^{2}$ Oxford Brookes University, Department of Accounting, Finance and Economics, UK \\ ${ }^{3}$ University of the Aegean, Department of Business Administration, Chios, Greece \\ ${ }^{4}$ University of Athens, Athens, Department of Economics, Greece
}

\begin{abstract}
The purpose of this paper is to examine the impact of terrorism on tourism demand in Greece using monthly data from 1977 to 2012. We investigate whether this relationship is bidirectional and whether it exhibits long run persistence. Thus, we employ a large dataset of terrorist incidents and perform cointegration and long-run causality tests, correcting our data for cyclical seasonality and applying PCA to construct a terrorism proxy according to the severity of the incident. Our findings concur that terrorism has a significant negative impact on tourist arrivals to Greece and that causality is noted from terrorism to tourism only. The results suggest that authorities should establish firm measures against terrorism and that further actions should be taken to promote tourism, safety and security, as a response to terrorist incidents. Our study is, to the best our knowledge, the first to approach terrorism using a three-factor proxy with qualitative features.
\end{abstract}

Keywords: Terrorism, tourism demand; cointegration; error correction models JEL classifications: C32, L83

* Corresponding Author: College of Business, Zayed University, P.O. Box 144534, Abu Dhabi, United Arab Emirates, Tel.:+971 2599 3474, Mail: Aristeidis.Samitas@zu.ac.ae 


\section{Introduction}

The past few years have seen a significant rise of terrorist incidents worldwide. These incidents usually relate to domestic political problems, even though we have recently experienced incidents relating to international geopolitical differences. Greece has been dealing with terrorist incidents from as far back as 1974, despite its relative political stability during this time. Being a top tourist destination, with $18.5 \%$ of GDP being attributed to the tourist industry (WTTC, 2017), Greece is an interesting case study on how terrorist events can affect tourist arrivals, since tourism is one of the most highly vulnerable industries resulting in huge economic losses for the economy. Bearing in mind the latest tourist attacks worldwide, this study aims to examine the existence and the direction of the link between terrorism and tourism.

As stated earlier, the total contribution of tourism earnings in Greece was 32.8 bn Euros (18.5\% of GDP) in 2016 and is expected to rise by $4.6 \%$ per annum to reach $23.8 \%$ of GDP by 2027 (WTTC, 2017). In the recent WTTC 2016 report, Greece is ranked 29th worldwide, in terms of absolute earnings, with its tourism industry contribution to GDP being much higher than the EU average of $10.2 \%$. While there are a number of determinants that influence the decision to travel to a particular destination, terrorist acts have a clear negative impact, because, unlike other factors, they are outside the tourists' control. Subsequently, tourist preferences for a safe travel destination can affect countries vulnerable to terrorist attacks. Greece has suffered a number of terrorist incidents perpetrated by certain terrorist organisations such as $1^{\text {st }}$ May, Revolutionary People's Struggle (ELA) and November 17 Revolutionary Organisation (N17RO). While Greek economy relies heavily on its burgeoning and sizeable tourism sector, the latter is highly vulnerable to terrorism activities, resulting in huge economic losses. Finally, Greece presents particular interest as a case study on terrorism since it is currently one of the top destinations for international tourists, while tourism is the only "heavy industry" of the Greek economy. Also, Greece is the only country which has experienced massive terrorist attacks for an extended period of time and is thus ideal for a time series study.

Terrorist acts are not only aimed at direct and immediate casualties, but are targeted at a larger audience in order to succeed in a political or social cause through violence or the threat of violence. The existence of a political or social objective is important because it is the differentiating element between terrorism and criminal acts. Terrorism can be domestic or transnational, with a clear distinction proposed by Enders et al (2011). Consequently, terrorist incidents affect more than the immediate victims. Schmid and Muldoon (2013) showed that a perceived threat negatively affects public well-being, even though Rubin and 
Wessely (2013) suggested that the psychological effect for most individuals will fade in the long run.

Almost every survey on the views of prospective tourists following terrorist incidents suggests that terrorism affects tourism. However, while informative, these surveys do not account for the fact that the memory of such incidents may fade or that the surveyed potential tourists can be tempted by low prices and special offers. Hence, historical data analysis with appropriate methods provides a clearer and better understanding of the effects of terrorism on tourism demand (Enders and Sandler, 1991). However, noting the dearth of empirical evidence for Greece, this paper explores this relationship with the use of cointegration and causality tests, utilising a relatively large sample of monthly data on terrorism incidents and visitor arrivals over the period 1977-2012. Furthermore, the cyclical seasonality is purged from the tourist arrivals series and from the three proxies of terrorism (terrorist incidents with casualties only, terrorist incidents with no casualties and terrorist incidents) and a common factor is selected using the Principal Components Analysis (PCA) in order to avoid multicollinearity problems. Finally, our work also demonstrates the long-run persistence of the negative effect of terrorist incidents on tourist demand, a finding with important policy implications.

This paper contributes to four aspects of the current literature. First, it establishes the relationship between terrorism and tourism, in a country with a heavy tourism industry, such as Greece. Second, it shows that this relationship is unidirectional, from terrorism to tourism only, even though our results relate mainly to domestic terrorism. Third, it demonstrates that the negative impact of terrorist incidents in Greece is persistent in the long run and is not limited to a short run drop in demand. Lastly, it complements existing studies on tourism and terrorism using a different methodology to proxy terrorist incidents according to the severity of the incident and an extensive dataset of terrorist incidents, corrected for seasonality.

The rest of this paper is structured as follows: Section 2 presents the relevant literature linking tourism and terrorist incidents, Section 3 presents the methodology and the data set used, Section 4 presents our empirical findings and Section 5 concludes.

\section{Literature Review}

A plethora of studies exist in the existing literature that show a positive relationship between tourism and economic growth (Balaguer and Cantavella-Jorda, 2002; Gunduz and Hatemi, 2005; Skerritt and Huybers, 2005; Eeckels et al, 2012; Dritsakis, 2012). 
Skavronskaya et al (2017) establish the "hedonic nature" of travel, using a series of cognitive psychology studies to examine what drives tourists to pick a particular destination. Buhalis (1999) also suggests that cultural and historical resources are often an important factor, price competitiveness notwithstanding. Saha and Yap (2014) examine 139 countries and show that political stability is an important factor for tourist arrivals, while Leung et al (2013) examine the role of social media in the decision-making process. Reversing the causality, Causevic and Lynch (2013) and Webster and Ivanov (2014) show how a booming tourism industry can be used as vehicle to promote political stability.

Studies pertaining to the influence of terrorism on tourism are mainly focused on examining the reduction in the number of tourists, the subsequent lost revenues in the industry and the temporal structure of the effects. While the methodologies employed vary, the conclusion remains that terrorist is decisively harmful and has severe negative repercussions on the hospitality sector and, thus, to GDP. Early literature notes evidence that international experience of tourists affects their reaction to terrorist incidents and the decision to travel to safer destinations which becomes economically damaging for countries where the frequency of terrorist incidents is high or growing (Cook and McCleary, 1983; D'Amore and Anuza, 1986; Hartz, 1989; Martin and Gu, 1992; Sonmez and Graefe, 1998; Enders et al, 1992; Seddighi et al, 2001; Araña and León, 2008). A few studies examine the causal relationship and confirm a unidirectional negative causality from terrorism to tourism. Among these, we note Enders and Sandler (1991) for Spain, Bhattacharya and Kaushik (2010) for India, Feridun (2010) for Turkey, Bassil et al (2015) for Lebanon and Raza and Jawaid (2013) for Pakistan.

Further, Enders and Sandler (1991) note that the terrorist incidents time series appears to be autonomous, which is consistent with the fact that terrorist attacks are random, and that a typical transnational terrorist incident scares away approximately 140,000 foreign visitors. In another study, Enders et al (1992) note that terrorism has an unfavourable effect on revenue gained from tourism in Greece, Italy, Austria and other Western European countries. The empirical results show that terrorism did not have a significant effect on tourism revenues of France, Denmark, Germany, the Netherlands, Norway, and Finland. On the other hand, tourism revenues in Greece, Italy and Austria were deteriorated by terrorist attacks and thus were sensitive to the adverse generalisation effects in the neighbouring countries (Sonmez, 1998; Enders et al, 1992).

The impact of terrorism on local and foreign tourism market can be different. Fleischer and Buccola (2002) show that foreign demand is price elastic while local demand is responsive to regional terrorism, the latter reinforcing that price reductions aimed at compensating for the impact of terrorism and hence attract more local tourists cannot be used as an effective strategy. In a cross-country analysis, Drakos and Kutan (2003) investigate 
the impact of terrorism on Greece, Israel, and Turkey, using monthly data from 1991 to 2000 with Italy as a control country. They show that, in Greece, high intensity attacks have an immediate negative impact domestically. On the other hand, low intensity attacks in neighbouring countries like Israel and Turkey seem to result in tourist flows to Greece, while medium and high intensity attacks result in a shift of tourist demand to Italy. Aschauer (2010) builds a theoretical model including crisis-stable factors as well as behavioural characteristics to show that the effects of terrorism may differ according to gender or culture.

\section{Methodology}

\subsection{The Data Set}

Monthly data from January 1977 to December 2012 on tourist arrivals are sourced from the statistical databases of National Statistical Services of Greece (NSSG) and terrorist incidents are drawn from the Global Terrorism database (START 2014). According to the NSSG, the principal reasons why tourists travel to Greece are summer vacations, visiting archaeological sites and other leisure purposes. All the above data is integrated in a single tourist arrival time series.

Regarding terrorist incidents, considering the period of interest and the fact that reliance on official terrorism statistics is often mistaken due to erroneous or concealed information, we processed the original complete database of 1,056 terrorism incidents in Greece (1970-2012) as follows:

1. Cases where no terrorist group claimed responsibility for the attack or the government is not certain for the authentication of the terrorists' declaration were excluded (388 events). This was mainly due to the fact that these terrorist incidents were low scale incidents and therefore it was uncertain whether they were indeed for terrorist purposes.

2. Incidents that did not take place on Greek land or airspace were excluded (5 events).

3. Two incidents with reference to a bomb explosion in a civilian airplane flying over Greek airspace and a hijacking without any clear trace of perpetrators were excluded.

4. Three incidents claimed by the November 17 Revolutionary Organisation were added.

Following the above process, the final dataset includes 664 terrorist incidents, of which 39 caused a total of 112 deaths. A time series with 432 months of observations was assembled. Each observation includes the monthly number of all the incidents, the monthly 
number of incidents with casualties and the name of the terrorist group that claimed responsibility.

The monthly tourist arrivals series had strong seasonal movements. First, we purged the cyclical seasonal movements from the series and extracted its underlying trend component. The terrorism proxy variables were grouped as (a) kill (terrorist incidents with casualties only), (b) terror (terrorist incidents with no casualties) and (c) terror_kill (total number of terrorist incidents. The main characteristics of these variables are that they are highly qualitative and indicate the presence or absence of one or more terrorism incidents in a month period. Further, the intensity of these incidents is different even in the same group. For example, the accidental death of the civilian Thanos Axarlian does not have the same gravity with the assassination of the active parliamentary member Pavlos Bakoyannis. Consequently, terrorism as an explanatory variable behaves like dummy variables.

In order to avoid problems regarding the nature of these variables such as the unnecessary element of problematic multicollinearity, we use the PCA method in order to extract a common factor from those three terrorism proxies. The PCA suggests the existence of a sole common factor (the eigenvalue for the $1^{\text {st }}$ factor was 2.135 and then fell below the threshold level of 1). This factor is used as a proxy for the terror variable which is used in the empirical analysis. An advantage of using this approach is that we have a continuous series instead of three different dummy variable proxies.

\subsection{Unit root}

To examine the order of integration of tourism and terror, the Augmented D-F (Dickey and Fuller 1979) test and the P-P test (Phillips and Perron 1988) are applied. Integration testing is required in order to confirm the stationarity of the data, before examining for a statistical relationship.

The equation for the ADF test is the following:

$$
\Delta \mathrm{Y}_{\mathrm{t}}=\alpha_{0}+\alpha_{1} \mathrm{t}+\varphi \mathrm{Y}_{\mathrm{t}-1}+\sum_{\mathrm{i}=1}^{\mathrm{n}} \gamma_{\mathrm{i}} \Delta \mathrm{Y}_{\mathrm{t}-\mathrm{i}}+\varepsilon_{\mathrm{t}}
$$

where $\Delta$ is the difference operator, $\varepsilon_{t}$ is a stationary random error term, $Y_{t}$ (either tourism or terror) is the series under examination, and $n$ is large enough to ensure that $\varepsilon_{t}$ is a white noise process. The number of lags $(n)$ to be used is identified using the Akaike Information Criterion. Null hypothesis of $Y_{t}$ being nonstationary is tested against the alternative of stationarity. When the estimated coefficient $\varphi$ is significantly negative the null hypothesis is rejected. The test takes three alternative forms: unit root (a) with an intercept and a time trend, as in equation (1); (b) with an intercept but no trend $\left(\alpha_{1}=0\right.$ in equation (1)); and (c) with no intercept, no trend $\left(\alpha_{0}=\alpha_{1}=0\right.$ in equation (1)). 
An alternative test is the P-P test. This test takes the form:

$$
\Delta \mathrm{Y}_{\mathrm{t}}=\alpha^{\prime}{ }_{0}+\alpha^{\prime}{ }_{1} \mathrm{t}+\rho^{*} \mathrm{Y}_{\mathrm{t}-1}+\varepsilon_{\mathrm{t}}^{\prime}
$$

where the standard notation as above is used. Here, the coefficient of consideration is $\rho^{*}$. When $\rho^{*}$ is sufficiently negative the null of nonstationarity is rejected. The P-P test addresses the unspecified autocorrelation and heteroskedasticity in the error process (Cang and Seetaram, 2012). Similarly to the ADF test, the P-P test has three different forms.

\subsection{Cointegration and error correction}

After confirming that the two time series are integrated of the same order, we examine the existence of cointegration, among the variables using the procedure of Johansen and Juselius (1990). We need to perform this procedure in order to confirm the use of the error correction model (see section 3.4), which will test for long run persistence of the relationship examined. The method is based on the unrestricted vector autoregression (VAR) model given as follows:

$$
Y_{t}=\mu+\sum_{k=1}^{p} \Pi_{k} Y_{t-k}+e_{t}
$$

where $(n \times 1)$ column vector of $n$ variables (i.e $I(d)$ with $\mathrm{d}>0)$, coefficient matrix, $(1 \times n)$ vector of constants, lag-length of the VAR and the error term are denoted by $Y_{t}, \Pi_{k}, \mu, p$, and $e_{t}$, respectively.

Hence, if $Y_{t}=\left[\right.$ tourism $_{t}$, terror $\left._{t}\right]$ is $\mathrm{I}(1)$, then with the first difference $\left(\Delta Y_{t}=Y_{t}-Y_{t-1}\right)$ equation (3) is specified as an error-correction (ECM) model as:

$$
\Delta Y_{t}=\mu+\sum_{k=1}^{p} \Gamma_{k} \Delta Y_{t-k}+\Pi Y_{t-1}+e_{t}
$$

where $\Gamma_{k}$ and $\Pi$ represent coefficient matrices. Note that $r$ refers to the rank and $\Pi$ is the matrix, the latter determining the cointegrating relations in the system, which is always smaller than the number of variables $(r<n)$ in $Y_{t}$. Since there are only two variables $(n=2)$ in the study, then either $r=0(\Pi=0)$, which implies no cointegration between the two variables, or $r=1$, which denotes cointegration (Herzer and Nowak-Lehmann 2004). In the ECM representation of equation (4), all variables are stationary and this avoids the problem of spurious results.

Two different statistics are used (Johansen and Juselius, 1990) in order to identify the rank of $\Pi$, and hence the number of cointegrating vectors. These are the trace statistic given by:

$$
\operatorname{Tr}=-\mathrm{T} \sum_{\mathrm{i}=\mathrm{r}+1}^{\mathrm{p}-2} \ln \left(1-\hat{\lambda}_{\mathrm{i}}\right)
$$


and the maximum eigenvalue statistic given by:

$$
\mathrm{L}-\max =-\mathrm{T} \ln \left(1-\hat{\lambda}_{\mathrm{r}+1}\right)
$$

where $\hat{\lambda}_{r+1}, \ldots, \hat{\lambda}_{p}$ are the $p-r$ smallest eigenvalues. The null hypothesis for equation (5) is that there exist at most $r$ cointegrating vectors. For equation (6), the null hypothesis is the presence of $r$ cointegrating vectors against $r+1$ cointegrating vectors. Since the estimations can be sensitive to the lag-selection, the Akaike information criterion is used for optimal lag-length.

\subsection{Long-run Granger causality}

In case where two nonstationary time series are cointegrated, an ECM specification should be estimated because a simple VAR in first differences is misspecified. In this paper, considering the case of two variables, the two cointegrated ECMs for tourism and terror are:

$$
\begin{gathered}
\Delta \text { tourism }_{\mathrm{t}}=\theta_{11}^{\mathrm{m}}(\mathrm{L}) \Delta \text { tourism }_{\mathrm{t}}+\theta_{12}^{\mathrm{n}}(\mathrm{L}) \Delta \text { terror }_{\mathrm{t}}+\pi_{1} \mathrm{ECM}_{\mathrm{t}-1}+\mathrm{a}_{1}+\mathrm{u}_{1 \mathrm{t}} \\
\Delta \text { terror }_{\mathrm{t}}=\theta_{21}^{\mathrm{m}}(\mathrm{L}) \Delta \text { tourism }_{\mathrm{t}}+\theta_{22}^{\mathrm{n}}(\mathrm{L}) \Delta \text { terror }_{\mathrm{t}}+\pi_{2} \mathrm{ECM}_{\mathrm{t}-1}+\mathrm{a}_{2}+\mathrm{u}_{2 \mathrm{t}}
\end{gathered}
$$

where

$$
\begin{aligned}
& \theta_{i j}^{m}(L)=\sum_{l=1}^{M_{i j}} \theta_{i j l} L^{1} \\
& \theta_{i j}^{n}(L)=\sum_{l=1}^{N_{i j}} \theta_{i j l} L^{1}
\end{aligned}
$$

with $L$ denoting the lag operator (i.e. $L Y_{t}=Y_{t-1}$ ). Here, $u_{1 t}$ and $u_{2 t}$ are disturbances that are not serially correlated and $E C M_{t-1}$ is the error-correction term (ECM) derived from the long-run relationship and is a stationary variable.

The null hypothesis of causality in the ECMs is different because two different sources of causation are present. The lagged coefficient implies short-run and the ECM implies the long-run causality, respectively.

The following cases are possible:

(a) Causality from terror to tourism if (i) the coefficients on the lagged terror variable $\left(\theta^{\mathrm{n}}{ }_{12}(\mathrm{~L})\right)$ in (7) are jointly statistically different from zero, (ii) the coefficient of the $\operatorname{ECM}\left(\pi_{1}\right)$ in (7) is statistically different from zero (non-zero), and (iii) both the lagged coefficients and the ECM are non-zero. 
(b) Causality from tourism to terror if (i) the coefficients on the lagged tourism variable $\left(\theta^{\mathrm{m}}{ }_{12}(\mathrm{~L})\right)$ in $(8)$ are jointly non zero, (ii) the coefficient of the ECM $\left(\pi_{2}\right)$ in (8) is non-zero, and (iii) both the lagged coefficients and the ECM are non-zero.

(c) Bidirectional causality if both $\left(\theta^{\mathrm{n}}{ }_{12}(\mathrm{~L})\right)$ in $(7)$ and $\left(\theta^{\mathrm{m}}{ }_{12}(\mathrm{~L})\right)$ in (8) together with their respective ECM are non-zero as a group.

(d) No causality relationship if all short-run dynamics and long-run coefficients are jointly non-zero for both cases.

\section{Empirical Results}

As a first step, ADF and P-P tests for detection of unit roots are used in order to examine whether the series are stationary. Table 1 reports the results of the two unit root tests for both variables. Both tests suggest the existence of unit roots in the levels (the null of unit root is not rejected for all three different model cases) and the absence of unit roots after obtaining first-differences of the series (the null is rejected for all three model cases). Therefore, from both ADF and P-P tests, it is concluded that the two series are I(1) and hence can be stationary after first-differencing.

\section{[Insert table 1 here]}

\section{[Insert table 2 here]}

Table 2 presents the results regarding the values of the trace and maximum eigenvalue statistics for possible cointegration among the variables. Both test statistics suggest the existence of 1 cointegrating relationship. Specifically, regarding the trace statistic, the null of $r=0$ is rejected in favour of the alternative that there is at least one cointegrating relationship ( $r>0$ ), while the null of $r \leq 1$ is not rejected concluding that there is indeed one cointegrating relationship. Further, the maximum eigenvalue statistic the null hypothesis of $r=0$ is rejected in favour of the alternative $r=1$, suggesting the existence of 1 cointegrating relationship. Therefore, it is concluded that there is a long-run trend connecting the two series. Next, the estimation of the long-run relationship and the ECM test results for both tourism and terror are reported in Table 4. The long-run relationship suggests that there is a strong negative effect (the coefficient is equal to -2) from terrorism to tourism while the ECM results suggest that there are statistically significant negative effects from terrorism to tourism both in the long-run and the short-run.

[Insert table 3 here] 
Finally, the empirical analysis is concluded with the examination of the direction of causality among the two variables (Table 4). It is observed that there is unidirectional causality from terror to tourism in the short-run $(F=4.852)$ with no evidence of reverse causality $(F=0.235)$. A similar conclusion is derived for the causality in the long-run based on the statistical significance of the lagged ECM term $(F=7.721)$. Additionally, when both the lagged ECM term and the short run dynamics are jointly tested, the null hypothesis of no causality $(F=6.429)$ is rejected. Importantly, causality from tourism to terror in any case is not detected and subsequently, it is concluded that terror has a decisive negative impact on tourism and the causality direction is from terrorism to tourism demand in Greece.

[Insert table 4 here]

\section{Conclusions}

In this paper, the negative effect of terrorism on tourism demand using Greece as a case study is verified. We also show that the effect is unidirectional (terrorist incidents affect tourism demand and not vice versa) and persistent in the long run. We employed an exhaustive data set, corrected for seasonality, and applied PCA to three grouped proxies for terrorism in order to extract a common factor and avoid multicollinearity problems. Despite the domestic nature of the terrorist incidents studied, our findings are significant, considering the escalation of incidents worldwide.

Given that the tourism-led growth hypothesis holds for Greece (Eeckels et al, 2012; Dritsakis, 2012), we can see that it is imperative for authorities to deal with terrorist incidents decisively, in order to protect the tourist sector. While the need to sustain high quality tourism infrastructure and services has been the focus for a long time, the negative effect of terrorism, albeit domestic, has not been taken into consideration. Authorities in Greece should be proactive in reducing terrorist activities in order to further boost tourist arrivals and boost the country's earnings.

Our findings are valid at the international level as well and are of particular importance in the current upsurge of violent acts in the EU, the US and tourist resorts worldwide. Apart from the immediate impact in casualties and injuries, the lingering result of terrorism is not only in changing everyday life, due to the threat of violence, but is also in harming income and reducing total output. Finally, since the negative economic repercussions remain in the long run, even after the psychological effects may have faded, it is important for authorities to implement strategies that deal with these repercussions directly. 
These strategies must be particularly aimed at the tourist industry, given the significant negative relationship established in this paper.

Future research on this topic may consider including other forms of tourism and taking into consideration the intensity of terrorism incidents. A drawback of using the number of incidents compared to the intensity is that the former makes no distinction between the gravity of the incidents. For example, while a politically-motivated property damage and a brutal assassination both count as a single incident, it is reasonable to assume that the assassination weights more. On the other hand, acts of blind violence, such as those recently experienced in Europe, would probably weigh more in deterring tourist arrivals. We propose that future studies use as a case study a country dealing with transnational terrorism, since these events have admittedly increased in frequency and gravity in last few years. 


\section{References}

Araña, J. E., \& León, C. J. (2008). The impact of terrorism on tourism demand. Annals of Tourism Research, 35(2), 299-315.

Aschauer, W. (2010). Perceptions of tourists at risky destinations. A model of psychological influence factors. Tourism Review, 65(2), 4-20.

Balaguer, J., \& Cantavella-Jorda, M. (2002). Tourism as a long-run economic growth factor: the Spanish case. Applied economics, 34(7), 877-884.

Bassil, C., Hamadeh, M., \& Samara, N. (2015). The tourism led growth hypothesis: the Lebanese case. Tourism Review, 70(1), 43-55.

Bhattacharya, M., \& Basu, K. (2010). Impact of terror incidents on the Foreign Tourist Arrivals in India: an econometric exploration. International Journal of Tourism Policy, 3(3), 213-222.

Buhalis, D. (1999). Tourism on the Greek Islands: Issues of peripherality, competitiveness and development. The International Journal of Tourism Research, 1(5), 341.

Cang, S. \& Seetaram, N. (2012). Time series analysis. In L., Dwyer, A., Gill, \& N., Seetaram (Eds.). Handbook of research methods in tourism: Quantitative and qualitative approaches. Edward Elgar Publishing.

Causevic, S., \& Lynch, P. (2013). Political (in) stability and its influence on tourism development. Tourism Management, 34, 145-157.

Cook, R. L., \& McCleary, K. W. (1983). Redefining vacation distances in consumer minds. Journal of Travel Research, 22(2), 31-34.

D’Amore, L. J., \& Anuza, T. E. (1986). International terrorism: implications and challenge for global tourism. Business Quarterly, 4, 20-29.

Dickey, D. A., \& Fuller, W. A. (1979). Distribution of the estimators for autoregressive time series with a unit root. Journal of the American Statistical Association, 74(366a), 427-431.

Drakos, K., \& Kutan, A. M. (2003). Regional effects of terrorism on tourism: Evidence from three Mediterranean countries. Journal of Conflict Resolution, 47(5), 621-641.

Dritsakis, N. (2012). Tourism development and economic growth in seven Mediterranean countries: a panel data approach. Tourism Economics, 18(4), 801-816.

Eeckels, B., Filis, G. \& Leonard, C. (2012). Tourism income and economic growth in Greece: Empirical evidence from their cyclical components. Tourism Economics, 18 (4), 817 - 834.

Enders, W., \& Sandler, T. (1991). Causality between transnational terrorism and tourism: The case of Spain. Studies in Conflict \& Terrorism, 14(1), 49-58. 
Enders, W., Sandler, T., \& Gaibulloev, K. (2011). Domestic versus transnational terrorism: Data, decomposition, and dynamics. Journal of Peace Research, 48(3), 319-337.

Enders, W., Sandler, T., \& Parise, G. F. (1992). An econometric analysis of the impact of terrorism on tourism. Kyklos, 45(4), 531-554.

Feridun, M. (2010). Impact of terrorism on tourism in Turkey: empirical evidence from Turkey. Applied Economics, 43 (24), 3349-3354.

Fleischer, A., \& Buccola, S. (2002). War, terror, and the tourism market in Israel. Applied Economics, 34(11), 1335-1343.

Gunduz, I., \& Hatemi, J. A. (2005). Is the tourism-led growth hypothesis valid for Turkey. Applied Economics Letters, 12 (8), 499-504.

Hartz, C. (1989). Business executives as international terrorist targets. In: J. R. Buckwalter, (Ed.), International terrorism: The decade ahead. The University of Illinois,

Herzer, D., \& Nowak-Lehmann, D. (2004). Export diversification, externalities and growth (No. 99). Discussion Papers/Universität Göttingen, Ibero-Amerika-Institut für Wirtschaftsforschung.

Johansen, S., \& Juselius, K. (1990). Maximum likelihood estimation and inference on cointegration with applications to the demand for money. Oxford Bulletin of Economics and Statistics, 52(2), 169-210.

Krakover, S. (2005). Estimating the effects of atrocious events on the flow of tourism to Israel. In G., Ashworth \& R., Hartmann (Eds.). Horror and human tragedy revisited: The management of sites of atrocities for tourism, 183-194. New York: Cognizant Communication.

Leung, D., Law, R., Van Hoof, H., \& Buhalis, D. (2013). Social media in tourism and hospitality: A literature review. Journal of Travel \& Tourism Marketing, 30(1-2), 3-22.

Martin, T. L., \& Gu, Z. (1992). Terrorism, seasonality, and international air tourist arrivals in central Florida: an empirical analysis. Journal of Travel \& Tourism Marketing, 1(1), 3-17.

Phillips, P. C., \& Perron, P. (1988). Testing for a unit root in time series regression. Biometrika, 75(2), 335-346.

Raza, S. A., \& Jawaid, S. T. (2013). Terrorism and tourism: a conjunction and ramification in Pakistan. Economic Modelling, 33, 65-70.

Rubin, G. J., \& Wessely, S. (2013). The psychological and psychiatric effects of terrorism: lessons from London. Psychiatric Clinics of North America, 36(3), 339-350.

Saha, S., \& Yap, G. (2014). The moderation effects of political instability and terrorism on tourism development: a cross-country panel analysis. Journal of Travel Research, 53(4), 509-521.

Seddighi, M. W., Nuttall, A. L., \& Theocharous, H. R. (2001). Does cultural background of tourists influence the destination choice? An empirical study with special reference to political instability. Tourism Management, 22 (2), 181-191. 
Schmid, K., \& Muldoon, O. T. (2015). Perceived threat, social identification, and psychological well being: The effects of political conflict exposure. Political Psychology, 36(1), 75-92.

Skavronskaya, L., Scott, N., Moyle, B., Le, D., Hadinejad, A., Zhang, R., ... \& Shakeela, A. (2017). Cognitive psychology and tourism research: state of the art. Tourism Review, 72(2).

Skerritt, D., \& Huybers, T. (2005). The effect of international tourism on economic development: an empirical analysis. Asia Pacific Journal of Tourism Research, 10 (1), 23-43.

Sonmez, S. (1998). Tourism, terrorism, and political instability. Annals of Tourism Research, 25 (2), 416-456.

Sonmez, S., \& Graefe, S. (1998). Influence of terrorism risk on foreign tourism decisions. Annals of Tourism Research, 25 (1), 112-144.

START (2014). National Consortium for the Study of Terrorism and Responses to Terrorism, University of Maryland.

Webster, C., \& Ivanov, S. H. (2014). Tourism as a force for political stability. The International Handbook on "Tourism and Peace", WTO

World Travel and Tourism Council (2017). Travel and Tourism Economic Impact: Greece. 
Table 1: ADF and PP test results for Unit Roots

\begin{tabular}{|c|c|c|c|}
\hline \multirow[b]{2}{*}{ Levels } & \multirow[t]{2}{*}{ terror } & \multicolumn{2}{|c|}{ Critical Values (5\%) } \\
\hline & & & \\
\hline$\tau_{\mathrm{T}}(\mathrm{ADF})$ & $-2.438[12]$ & $-1.499[7]$ & -3.422 \\
\hline$\tau_{\mu}(\mathrm{ADF})$ & $-2.234[12]$ & $0.764[7]$ & -2.869 \\
\hline$\tau(\mathbf{A D F})$ & $-1.183[12]$ & $3.362[7]$ & -1.941 \\
\hline$\tau_{\mathrm{T}}(\mathbf{P P})$ & $-1.494[0]$ & $-2.133[1]$ & -3.421 \\
\hline$\tau_{\mu}(\mathbf{P P})$ & $-1.219[2]$ & $-3.182[5]$ & -2.869 \\
\hline$\tau(\mathbf{P P})$ & $-1.212[3]$ & $0.537[9]$ & -1.941 \\
\hline \multicolumn{4}{|c|}{ First Differences } \\
\hline$\tau_{\mathrm{T}}(\mathrm{ADF})$ & $-10.362[11]^{*}$ & $-8.514[6]^{*}$ & -3.422 \\
\hline$\tau_{\mu}(\mathrm{ADF})$ & $-10.255[11]^{*}$ & $-8.428[6]^{*}$ & -2.869 \\
\hline$\tau(\mathbf{A D F})$ & $-10.269[11]^{*}$ & $-7.676[6]^{*}$ & -1.941 \\
\hline$\tau_{\mathrm{T}}(\mathbf{P P})$ & $-12.269[18]^{*}$ & $-20.955[5]^{*}$ & -3.422 \\
\hline$\tau_{\mu}(\mathbf{P P})$ & $-13.347[18]^{*}$ & $-20.214[2]^{*}$ & -2.869 \\
\hline$\tau(\mathbf{P P})$ & $-12.247[18]^{*}$ & $-20.227[3]^{*}$ & -1.941 \\
\hline
\end{tabular}

Notes: Numbers in parentheses denote the lag lengths and the bandwidths for the $\mathrm{ADF}$ and the PP tests respectively; $(*)$ denotes the rejection of the null hypothesis at the $5 \%$ level. The models are as follows: $\tau_{\mathrm{T}}$ is the model with a drift and a trend, $\tau_{\mu}$ is the model with a drift, and $\tau$ is the model without a drift and trend. 
Table 2: Cointegration Test Results

\begin{tabular}{lcc}
\hline Null Hypothesis & $\begin{array}{c}\text { Trace } \\
\text { Statistics }\end{array}$ & $\mathbf{5 \%}$ critical \\
\hline None ${ }^{*}$ & 35.35 & 15.41 \\
At most 1 & 2.71 & 3.76 \\
\hline Null Hypothesis & Max Statistics & $\mathbf{5 \%}$ critical \\
\hline None ${ }^{*}$ & 29.29 & 14.07 \\
At most 1 & 2.71 & 3.76 \\
\hline Notes: $\left({ }^{*}\right)$ denotes the rejection of the null hypothesis at the $5 \%$ level \\
\hline
\end{tabular}


Table 3: Long-Run Test Results

\begin{tabular}{|c|c|c|}
\hline Variables & $\begin{array}{c}\text { Equation } 1 \\
\text { tourism }_{t}\end{array}$ & $\begin{array}{c}\text { Equation } 2 \\
\text { terror }_{t}\end{array}$ \\
\hline$E C M_{t-1}$ & $\begin{array}{l}-0.004^{*} \\
(-9.046)\end{array}$ & $\begin{array}{c}-0.340 \\
(-1.816)\end{array}$ \\
\hline$\Delta$ tourism $_{t-1}$ & $\begin{array}{l}-0.056^{*} \\
(-2.071)\end{array}$ & $\begin{array}{c}0.282 \\
(0.654)\end{array}$ \\
\hline$\Delta$ tourism $_{t-2}$ & $\begin{array}{c}-0.120 \\
(-1.274)\end{array}$ & $\begin{array}{c}0.031 \\
(0.071)\end{array}$ \\
\hline$\Delta$ terror $_{t-1}$ & $\begin{array}{l}-0.005 * \\
(-2.605)\end{array}$ & $\begin{array}{c}-0.177 \\
(-1.597)\end{array}$ \\
\hline$\Delta$ terror $_{t-2}$ & $\begin{array}{l}-0.009 * \\
(-3.427)\end{array}$ & $\begin{array}{c}-0.014 \\
(-0.259)\end{array}$ \\
\hline Constant & $\begin{array}{c}0.005 \\
(0.588) \\
\end{array}$ & $\begin{array}{c}-0.001 \\
(-0.016)\end{array}$ \\
\hline $\begin{array}{l}\text { Adj. R-squared } \\
\text { F-statistic } \\
\text { DW statistic }\end{array}$ & $\begin{array}{c}0.610 \\
41.775 \\
2.169 \\
\end{array}$ & $\begin{array}{c}0.424 \\
55.067 \\
1.916 \\
\end{array}$ \\
\hline
\end{tabular}

Notes: ECM $_{t-1}$ is given by tourism $_{t-1}=13.16-2.004 *$ terror $_{t-1} ;$ Values of t-statistics are reported in parentheses. $\left({ }^{*}\right)$ denotes statistical significance at $5 \%$ level. The sample is from 1977:01 - 20012:12 (432 observations). 
Table 4: Long Run Granger Causality Test Results

\begin{tabular}{lcc}
\hline Null Hypothesis: & F-Statistic & Prob \\
\hline terror does not Granger Cause tourism & $4.852^{*}$ & 0.008 \\
tourism does not Granger Cause terror & 0.235 & 0.791 \\
$\boldsymbol{E C M}_{\boldsymbol{t}-1}$ does not Granger Cause tourism & $7.721^{*}$ & 0.001 \\
$\boldsymbol{E C M}_{\boldsymbol{t}-1}$ and tourism do not Granger Cause terror & 0.721 & 0.486 \\
$\boldsymbol{E C M}_{\boldsymbol{t}-1}$ and terror do not Granger Cause tourism & $6.429^{*}$ & 0.002 \\
$\boldsymbol{E C M}_{\boldsymbol{t}-\mathbf{1}}$ does not Granger Cause terror & 2.190 & 0.113 \\
\hline Notes: $\left(^{*}\right)$ denotes the rejection of the null of no causality at the 5\% level; Lag-length used is of order 2; \\
Sample is from 1977:01 - 2012:12 (432 obs)
\end{tabular}

